DOI 10.37882/2223-2982.2020.09.24

\title{
НОВОЕ НАПРАВЛЕНИЕ В СОВРЕМЕННОЙ ЛИНГВИСТИКЕ - ЛАВАНДОВАЯ ЛИНГВИСТИКА
}

\section{A NEW DIRECTION IN MODERN LINGUISTICS - LAVENDER LINGUISTICS}

A. Ottuszyk

Summary: The article is devoted to the current problem of a new direction in modern linguistics, the so-called Lavender linguistics, also known by the concept of Gayspeak, LGBT language or pink language. Since this problem is relatively young, it has been little studied and requires further research. This trend in modern linguistics makes it possible to study the characteristics of speech of a group of people who differ in their sexual orientation. The author gives two examples from the field of lavender linguistics, namely the phenomenon of the polar language in Great Britain, as well as the jargon of the homosexual community in the Polish People's Republic. In addition, the article reveals the contents of the abbreviation LGBT.

Keywords: lavender linguistics, pink language, LGBT, polari, LGBT research.

\author{
Олтушик Алина Барбара \\ Аспирант, Московский государственный \\ психолого-педагогический университет \\ oltuszyk.alina.a@gmail.com
}

Аннотация: Статья посвящена актуальной проблеме нового направления в современной лингвистике, - так называемой Лавандовой лингвистике, известной также под названием гей-язык (англ. «Gayspeak»), язык ЛГБТ или розовый язык. Так как данное направление является относительно молодым, оно мало изучено и требует дальнейших исследований. Данная тенденция в современной лингвистике дает возможность изучения особенностей речи группы людей, отличающихся сексуальной ориентацией. Автор приводит в статье два примера из области лавандовой лингвистики, а именно феномен языка поляри в Великобритании, а также жаргон гомосексуального сообщества в Польской Народной Республике.

Ключевые слова: лавандовая лингвистика, розовый язык, ЛГБТ, поляри, исследования ЛГБТ.

Д.Б. Вершинина подчеркивает, что «Квир-теория обогатила тематику и проблематику гендерных исследований, дав возможность не только изучать гомосексуальность, но и анализировать, как на разных исторических этапах конструировалась и поддерживалась так называемая гетеронормативная матрица. Квир-теория позволяет критически взглянуть и на сами гендерные исследования с точки зрения воспроизведения ими бинарности мышления (мужчины/женщины, маскулинное/феминное)»[6, 177].

Особенно значимы в связи с возникновением таких научных направлений ЛГБТ исследования, и квирисследования, по мнению А.П. Шевелевой, являются «размыванием границ между субъектом и объектом», где в призме внимания «значимость личности исследователя» $[17 ; 74]$.

Профессор Малгожата Кита пишет, что лавандовая лингвистика - это термин, лингвистический ярлык для обозначения области лингвистических исследований, которые представляют собой стиль, язык, а также языковое и коммуникативное поведение людей, называемых с помощью аббревиатуры ЛГБТ [9; 61].

Следует отметить, что изначально для этой группы людей существовал термин gay people (буквально переводится, как «люди гей»). Но поскольку термин gау (геи) все еще ассоциировался в основном с мужским полом, женщины-лесбиянки стали требовать, чтобы о них говорили 
так, как раньше, - lesbians (лесбиянки), и таким образом противодействовать их маргинализации. Фраза gay men and lesbians (геи и лесбиянки) должна была служить этой цели. Наконец, были добавлены другие группы, что привело к появлению таких терминов, как lesbian, gay, bisexual, transsexual/transgender(ed) (лесбиянки, геи, бисексуалы, транссексуалы/трансгендеры), включенных в аббревиатуру LGBT или GLBT. Кроме того, появилось слово queer, «квир», (буквально: «странный»), использование которого, с одной стороны, означало присвоение уничижительного термина гомосексуальному человеку, чтобы лишить его дополнительных коннотаций, а с другой стороны, это должно было стать термином, в совокупности описывающим людей с негетеросексуальными предпочтениями. Включив это слово, была создана аббревиатура LGBTQ, и добавив questioning «есть сомнения относительно их собственного пола или сексуальной ориентации» - LGBTQQ. Тем не менее, наиболее часто используемая форма попрежнему ЛГБТ [8; 141].

«Язык лаванды» использует разные языковые уровни, от фонетического до стильного и текстового, и, наконец, дискурсивный. Он также включает в себя паравербальный и невербальный кодекс - набор поведений, которые социально признаны как гомосексуальные или экологически понятные культурные коды, которые сигнализируют о гомосексуальной ориентации. Его многомерность также начинает появляться в недавних исследованиях польских лингвистов, которые очень заинтересованы в вопросах терминологии, а также в текстуализации и дискурсивности языка LGBTQ [9; 62-63].

В польской лингвистике кроме терминов «Лавандовая лингвистика» или «лавандовый язык», существует также термин «розовый язык». Профессор Бартош Варкоцки считает, что фраза «розовый язык» идеально соответствует дискурсу ЛГБТ, оправдывая свое мнение следующим образом: «У всех нас есть розовый язык, это правда. Вы также можете высунуть язык насмешливым жестом, хотя это не всегда хорошо кончается. Язык липкий, плотский и сексуальный. «Розовый язык» должен быть прежде всего синонимом дискурса о гомосексуализме в начале XXI века. Однако буквальность «метафоры» (розовый язык - это здоровый и нормальный язык) была для меня неотразимо соблазнительной. Настолько, что я начал смотреть на «розовый язык» парадоксальной универсальности, как «белые зубы» из дебютного романа Зади Смит. Если бы дорогие читатели увидели нечто подобное, успех книги был бы полным» [3; 14-15].

В дискурсе ЛГБТ цвет лаванды важен и хорошо вписывается в данную культуру. Это может оправдать называние лингвистической тенденции, посвященной изучению языковых проблем и использованию языка в такой специфической группе пользователей (носителей), как лавандовая лингвистика.
Одним из самых ярких примеров Лавандовой лингвистики является недавно систематизированный британский «язык» (диалект/жаргон/сленг) поляри. «Основа современного языка гей-сообщества - Polari, - секретный язык маргинальных групп гей-населения. Именно его секретность стала причиной невозможности изучения этого явления до кардинальных экономических трансформаций» $[18 ; 3]$. Но этот термин включает в себя не только прошлый «секретный» гей-сленг, но и воровской жаргон, жаргон преступного мира проституции и наркоманов, жаргон моряков, элементы кокни в Восточном Лондоне и связанный с ним рифмующийся сленг, а также слова обратного сленга. С другой стороны, поляри - это также аллюзивный жаргон некоторых британских телевизионных программ, особенно с шестидесятых годов, до появления гомосексуальных правил в 1967 году. Он также содержит смесь слов, заимствованных из идиша. Название «поляри» происходит от итальянского языка parlare. Конечно, только некоторые слова, включенные в поляри, перешли в разговорный язык, не все из них были бы понятны и современному британскому гею [7; 123].

В Польской Народной Республике (1947-1989), по мнению нескольких ученых, в том числе Й. Буршты, также наблюдался характерный способ общения людей нетрадиционной сексуальной ориентации. Гомосексуальное сообщество того времени, очевидно, характеризовалось отдельным «жаргоном» - «розовым языком», который представляет собой такой же набор слов и ассоциаций, как и характерный стиль речи и мышления об их «инаковости». Это был язык, наполненный жаргонными терминами, код, распознаваемый только инсайдерами и основанный на аллюзиях, предложениях, ничего прямо не называя. Существует несколько отдельных аспектов, которые чаще всего повторяются в отдельных повествованиях: это самоидентификация и, следовательно, размышление о том, как и с помощью каких определений или категорий идентичности строится повествование о «раскрытии» своего сексуального различия; отношения с близкими родственниками; характерные черты «жаргона» гомосексуальных сообществ, его аллюзивность, игривость и подрывной потенциал. Кроме того, Й. Буршта замечает, что общими чертами для этой социальной группы являются чувство отчужденности и инаковости, исключения из общества, которое выражается в том, что они называют себя «другими» и используют гетеронормативную лексику для идентификации своих партнеров, которых называют просто - «друзьями» [2; 24-25].

Лавандовая лингвистика в настоящее время становится все более популярной, особенно на Западе, где предметы, связанные с нетрадиционной сексуальной ориентацией, не вызывают столько противоречий, как в России или Польше. Хотя следует отметить, что гендерная лингвистика, которую можно назвать «предшественником» лавандовой лингвистики в России, находится на очень высоком уровне. 
Можно задать вопрос, существует ли сегодня польский или русский язык/ЛГБТ-сленг? Ответом может послужить мнение профессора из Варшавского Университета Кжиштофа Заблоцкого: «Несомненно, такой код и такой язык существуют, вероятно, каждый сможет вспомнить некоторые «тематические» слова или фразы или примеры невербального общения. Но я думаю, что эти вопросы следует рассматривать в несколько более широком культурно-языковом контексте» $[7 ; 121]$.
Таким образом, Лавандовая лингвистика в настоящее время привлекает большое внимание лингвистов в мире, так как сексуальные меньшинства в последние годы получили большой импульс для развития и заявления о себе в широком общественном поле, в связи с чем начали развиваться язык и особенности произношения, дискурсивные характеристики речи представителей гей-сообществ. И изучение данного направления лингвистики становится задачей современного языкознания.

\section{ЛИТЕРАТУРА}

1. Bulter J., Uwikani w Płeć. Feminizm i polityka tożsamości, Warszawa 2008.

2. Burszta J.,„Do czego się było przyznawać, jak nie istniał homoseksualizm?" Różowy język w narracjach pamięci o męskiej homoseksualności w PRL [online:] https://link.do/BOdIM (15.03.2020).

3. Warkocki B., Różowy język. Literatura i polityka kultury na początku wieku, Warszawa 2013.

4. Warkocki B., Trzy fale emancypacji homoseksualnej w Polsce [w:] Porównania 15, Poznań 2014.

5. Winnicka E., Dlaczego nie możemy o tym rozmawiać... [w:] „Polityka” 39, 2003

6. Вершинина Д.Б. Гендерные аспекты истории запада: основные дискуссионные поля // Вестник пермского университета: история . — Выпуск 4 (39) . — Пермь, 2017.

7. Zabłocki K., Luj przyjacielem Dorotki? Meandryczne meta refleksje o tęczowym języku z filologiczno komparatystycznym przegięciem [w:] InterAlia. Pismo poświęcone studiom queer 2019; 14 (14).

8. Krzyszpień J. Język i emancypacja LGBT: uwagi praktyczne [w:] Queer Studies. Podręcznik kursu, Warszawa 2010.

9. Kita M., Czy potrzebna jest lawendowa lingwistyka? [w:] Polonistyka Na Początku Xxi Wieku: Diagnozy Koncepcje Perspektywy, Tom III, Współczesne Aspekty Badań Nad Językiem Polskim - Teoria I Praktyka, Katowice, 2018, s. 61-73.

10. Kurpios P., Poszukiwani, poszukiwane. Geje i lesbijki a rzeczywistość PRL. [w:] Zeszyty Kulturoznawcze 1, 2003.

11. Lis B., Seksualne obywatelstwo i nieheteronormatywne doświadczanie przestrzeni [w:] Kultura Popularna, nr 2 (24), 2009.

12. Rejert A., Płeć - język - kultura, Katowice 2013.

13. Словарь терминов межкультурной коммуникации / И.Н. Жукова, М.Г. Лебедько, З.Г. Прошина, Н.Г. Юзефович; под ред. М.Г. Л ебедько и 3.Г. Прошиной. — М. : Флинта : Наука, 2013. — с 225.

14. Уэст К., Зиммерман Д. Создание гендера // Хрестоматия феминистских текстов / под ред. Е. Здравомысловой, А. Темкиной. СПб.: Дмитрий Буланин. 2000.

15. Устинкин С.В., Рудакова Е.К., Эминов Д.С. Гендерные стратегии «мягкой силы» НПО как инструмент переформатирования культурного кода общества и государства в России // Власть, (1). - 2016.

16. Здравомыслова Е., Темкина А. Феминистские рефлексии о полевом исследовании // Laboratorium. 2014. 6 (1): 84-112.

17. Шевелева А.П. Проблема изучения культур и практик «невидимых» групп //Вестник РГГУ. Серия: Литературоведение. Языкознание. Культурология. 2013.

18. Шилин В.А. Концептуальная метафора в языке англоговорящего гей-сообщества // Научно-практический электронный журнал аллея науки №3(19) 2018 - Симферополь, 2018. 